Sains Malaysiana 50(7)(2021): 1959-1970

http://doi.org/10.17576/jsm-2021-5007-11

\title{
Potential of Hibiscus sabdariffa Linn. Polyphenol-Rich Extract in Improving Diabetes-Induced Vascular Functional and Structural Abnormalities in Rats
}

(Potensi Ekstrak Hibiscus sabdariffa Linn. Kaya Polifenol Membaikpulih Ketaknormalan Fungsi dan Struktur Vaskular Aruhan Diabetis pada Tikus)

\author{
Fatin Farhana Jubaidi, SatiRah Zainalabidin, Lai Ying, Nur LiYana Mohammed Yusof \& Siti Balkis \\ BUDIN*
}

\section{ABSTRACT}

Hibiscus sabdariffa Linn. contains a high concentration of polyphenolic compounds and shows potentials in reducing vascular complications in diabetes mellitus (DM) patients. This study was aimed to determine the ability of $\mathrm{H}$. sabdariffa Linn. polyphenol-rich extract (HPE) in improving vascular endothelial dysfunction and attenuating oxidative stress in type 1 DM. DM was induced in adult male rats and the rats were then divided into three groups; untreated DM (DM); DM with HPE supplementation (DM+HPE); and DM with metformin (DM+MET). Another group of non-diabetic rats served as the normal control group. These rats were left untreated for four weeks before being subjected to the supplementations for another four weeks. The thoracic descending aorta was isolated from the treated and untreated rats to measure the vascular reactivity, oxidative stress, and morphological alterations. The results showed that HPE supplementation significantly reduced the systolic blood pressure (SBP) and mean arterial pressure (MAP) in the DM+HPE group ( $p<0.05)$. HPE also showed a tendency to improve endothelium-dependent vasorelaxation compared to the untreated diabetic rats. Rats treated with HPE exhibited a considerable improvement in the activities of antioxidants and significantly attenuated oxidative damage $(p<0.05)$. Histological findings showed that HPE supplementation improved morphological changes in the aorta. In conclusion, HPE supplementation reduces vascular abnormalities in DM condition probably via amelioration of oxidative stress.

Keywords: Antioxidants; contractile response; oxidative stress; relaxation response; roselle

ABSTRAK

Hibiscus sabdariffa Linn. mengandungi sebatian polifenol yang tinggi dan menunjukkan potensi dalam mengurangkan komplikasi vaskular dalam keadaan diabetes melitus (DM). Kajian ini bertujuan untuk mengenal pasti sama ada ekstrak kaya polifenol H. sabdariffa Linn. (HPE) berupaya untuk meningkatkan fungsi vaskular serta membaikpulih tekanan oksidatif dalam DM jenis 1. DM diaruh pada tikus jantan dewasa dan kemudiannya tikus-tikus ini dibahagikan kepada tiga kumpulan: DM tanpa rawatan (DM); DM dengan suplementasi HPE (DM+HPE); dan DM dengan rawatan metformin $(D M+M E T)$. Satu kumpulan tikus normal dijadikan kumpulan kawalan normal. Kesemua tikus ini dibiarkan tanpa apaapa rawatan selama empat minggu sebelum rawatan mula diberi kepada setiap kumpulan selama empat minggu berikutnya. Aorta toraks menurun diasingkan untuk pengukuran reaktiviti vaskular, tekanan oksidatif dan perubahan morfologi. Hasil kajian mendapati suplementasi HPE didapati menurunkan tekanan darah sistolik (SBP) dan purata tekanan arteri $(M A P)$ secara signifikan $(p<0.05)$ dan menunjukkan kecenderungan untuk memulihkan vasorelaksasi endotelium berbanding tikus DM. Suplementasi HPE turut menunjukkan peningkatan pada aras aktiviti antioksidan di samping memulihkan tekanan oksidatif secara signifikan ( $<<0.05)$. Perubahan morfologi aorta juga dipulihkan dengan suplementasi HPE. Kesimpulannya, suplementasi HPE didapati berupaya mengurangkan ketaknormalan vaskular dalam keadaan DM mungkin melalui pemulihan tekanan oksidatif.

Kata kunci: Antioksidan; rosel; tekanan oksidatif; tindak balas mengecut; tindak balas relaksasi 


\section{INTRODUCTION}

Diabetes mellitus (DM) is a chronic metabolic disorder and a risk factor for cardiovascular diseases (CVD) that hold a strong association with vascular dysfunction and remodelling (Budin et al. 2018). Diabetic patients possess a higher risk of developing atherosclerosis and other types of CVD (Grundy et al. 2012). CVD is the principal cause of death worldwide, and the mortality rate is projected to increase exponentially each year. It is expected to increase two to five-fold over the next two decades in many countries such as India, China, and the United States (Alberti et al. 2013). Impaired vascular reactivity has been identified as one of the early markers in DM-induced vascular complications by altering the vascular responsiveness to contract and relax (Zainalabidin et al. 2018). Hyperglycaemia-induced aortic oxidative damage appears to act as a possible mechanism of impaired vascular reactivity (Ren et al. 2016), leading to the pathogenesis of vascular complications such as hypertension (Boonla et al. 2014; Si et al. 2017). Reactive oxygen species (ROS) plays a significant role in controlling endothelial function and vascular contraction of endothelial smooth muscle as well as promoting structural remodelling that causes increased peripheral resistance and elevated blood pressure (Yap et al. 2016; Zainalabidin et al. 2014).

Treating diabetic-induced vascular dysfunction is not only financially burdening, but effective pharmacological agents could also cause undesirable side effects to the patients. Besides that, many patients find that it is tricky sticking to a new modified, healthy lifestyle. Considering this, some researchers are diverting their interest in finding alternative treatment in natural products. The use of natural products as alternative treatment may be influenced by culture, tradition, personal belief, geography as well as familial history (Baharom et al. 2016). Medicinal plants with a combination of hypoglycaemic activity and the capability to inhibit oxidative stress would be good for the prevention of vascular complications in diabetic conditions. Hibiscus sabdariffa Linn. extract has been documented to have medicinal values and exhibited antihyperglycemic effect, improved insulin resistance (Peng et al. 2011), and elicited antihypertensive (Si et al. 2017) and anti-hyperlipidaemic effects (Mohammed Yusof et al. 2018a; Ojeda et al. 2010). In addition, $H$. sabdariffa Linn. also contains high polyphenol bioactive compounds such as hibiscus acid, anthocyanins and quercetin, which contribute to its medicinal values and antioxidant properties. The antioxidant activities of these compounds were found to protect the vascular wall from oxidative damage (Peng et al. 2011; Si et al. 2017). H. sabdariffa Linn. was discovered to have potential in preventing aortic injury (Ramalingam et al. 2016) and vascular dysfunction ( $\mathrm{Si}$ et al. 2017) in nicotine administered rats. $H$. sabdariffa Linn. polyphenol-rich extract (HPE) was also found to protect against cardiac dysfunction and remodelling in the diabetic model by reducing oxidative damage and restores antioxidant activities (Mohammed Yusof et al. 2018a). However, its efficacy in alleviating vascular dysfunction in diabetic rats is still unknown. Hence, this study aims to investigate whether HPE is able to improve the vascular function and attenuate oxidative stress in type $1 \mathrm{DM}$ rat model.

\section{Materials AND Methods}

\section{PREPARATION OF HPE}

H. sabdariffa Linn. calyces were purchased from HERBagus Sdn. Bhd. (Kepala Batas, Pulau Pinang, Malaysia). HPE was extracted using a method established by Mohammed Yusof et al. (2018b). H. sabdariffa Linn. calyces were fine-grounded, extracted in methanol with constant stirring in a $60{ }^{\circ} \mathrm{C}$ water bath for $30 \mathrm{~min}$ and filtered. The filter residues were re-extracted twice in methanol. The filtrate was collected, pooled, and evaporated using a rotary evaporator at $4{ }^{\circ} \mathrm{C}$ with $20 \mathrm{mbar}$ vacuum. The dried methanolic extract was then solubilised in $10 \mathrm{~mL}$ deionized water $(\mathrm{pH} 2.3$ ) and partitioned with $10 \mathrm{~mL} n$-hexane and $10 \mathrm{~mL}$ ethyl acetate 3 times. Ethyl acetate soluble fraction was collected and evaporated to dryness using a rotary evaporator (Buchi, Switzerland). The final extract was stored at $-20{ }^{\circ} \mathrm{C}$ before use.

\section{STUDY DESIGN AND ANIMALS HANDLING}

Adult male Sprague-Dawley rats weighing between 200-250 g were supplied by Animal Unit, Faculty of Medicine, Universiti Kebangsaan Malaysia (UKM), Kuala Lumpur, Malaysia. The rats were allowed for free access to a pellet diet and tap water. The animal housing unit was maintained at $25-28{ }^{\circ} \mathrm{C}$ with $12 \mathrm{~h}$ dark/light cycles. The rats were acclimatised to the laboratory conditions for 7 days before the commencement of the study. This study design was approved by the Universiti Kebangsaan Malaysia Ethics Committee (UKMAEC) (UKMAEC NO: FSK/2018/ BALKIS/28-MAR./915-MAR.-2018-DEC-2020). Diabetic rats were induced with streptozotocin (STZ) $(60 \mathrm{mg} / \mathrm{kg}$, single intraperitoneal injection) while the nondiabetic rats were injected with normal saline intraperitoneally. After three days of STZ induction, fasting blood glucose 
was measured and rats with fasting blood glucose level exceeding $15 \mathrm{mmol} / \mathrm{L}$ were considered as diabetic and were included in the study (Mohammed Yusof et al. 2018a). After confirmation, the rats were then divided into three groups; untreated diabetic (DM); diabetes with HPE supplementation (DM+HPE); and diabetes with metformin treatment (DM+MET). Prior to the treatments, all rats were left untreated for four weeks. Metformin is a well-known and the main first line antihyperglycemic drug in DM management and was found to be able to restore macrovascular reactivity and improve vascular dysfunction in the aorta of diabetic rats (Sena et al. 2011). Therefore, metformin treatment was chosen as the positive control. Next, the rats in DM+HPE and DM+MET groups received HPE $(100 \mathrm{mg} / \mathrm{kg})$ and metformin $(150$ $\mathrm{mg} / \mathrm{kg}$ ) daily via oral gavage for another four consecutive weeks. Meanwhile, non-diabetic (NDM) and DM groups were only given normal saline. Fasting blood glucose level was monitored at the end of the $1^{\text {st }}, 4^{\text {th }}$ and $8^{\text {th }}$ weeks while body weight was monitored weekly. At the end of the $8^{\text {th }}$ week, blood pressure was measured using noninvasive tail-cuff measurement (Si et al. 2017). The rats were then deeply anaesthetised using ketamine-xylazine cocktail anaesthesia and the aortas were rapidly excised for further analysis.

\section{ASSESSMENT OF VASCULAR REACTIVITY}

Vascular reactivity of the thoracic aorta ring was measured as previously described by Si et al. (2017). The descending thoracic aorta, which was excised and isolated from the anaesthetised rat was immediately placed in cold KrebsHenseleit solution containing (in $\mathrm{mM}$ ) $120 \mathrm{NaCl}, 4.8 \mathrm{KCl}$, $1.2 \mathrm{KH}_{2} \mathrm{PO}_{4}, 25 \mathrm{NaHCO}_{3}, 11$ glucose, $2.5 \mathrm{CaCl}_{2}$, and 1.4 $\mathrm{MgCl}_{2}$. Prior to cutting the thoracic aorta into a 3-5 mm ring, the connective tissues, clotted blood and surrounding fats were carefully removed. The aortic rings were then mounted between 2 stainless steel wires each and tied with a cotton thread. These rings were maintained at 37 ${ }^{\circ} \mathrm{C}$ and continually aerated with $95 \% \mathrm{O}_{2}$ and $5 \% \mathrm{CO}_{2}$. The aorta rings were equilibrated at a resting tension of 1.0$1.5 \mathrm{~g}$ for $45 \mathrm{~min}$ and the change of tension in the aortic rings was measured using force transducer connected to PowerLab with LabChart 6 software (ADInstrument, Australia). A total of $120 \mathrm{mM} \mathrm{KCl}$ was then added to the organ bath to assess the ring viability. After washout, $\mathrm{KCl} 10^{-6} \mathrm{M}$ of phenylephrine (PE) was added to induce an isometric contraction. Following that, a single bolus of $10^{-4} \mathrm{M}$ acetylcholine (ACh) was added to assess endothelial integrity. The endothelium was considered intact when the aortic ring showed more than $60 \%$ of vasorelaxation relative to the pre-constriction value. For assessment of contractile response, PE $\left(10^{-9}\right.$ to $\left.10^{-4} \mathrm{M}\right)$ was added in a cumulative manner until a maximum response was achieved. A plateau response was obtained before the addition of a subsequent dose. PE pre-constriction $\left(10^{-6}\right.$ $\mathrm{M})$, which produced a $70-80 \%$ of the maximal response was used prior to adding any vasorelaxant. ACh $\left(10^{-9}\right.$ to $10^{-4} \mathrm{M}$ ) was added in a dose-dependent manner to assess endothelium-dependent vasodilation in rings, whereas sodium nitroprusside (SNP) $\left(10^{-9}\right.$ to $\left.10^{-4} \mathrm{M}\right)$ was added to assess endothelium-independent vasodilation. The concentration-dependent contractile responses to PE were expressed as percentages of the maximum contraction obtained from the highest $\mathrm{K}^{+}$. Relaxation responses for ACh and SNP were expressed as percentage inhibition of PE-induced peak contraction.

\section{OXIDATIVE STRESS AND ANTIOXIDANT STATUS EVALUATION}

A portion of the aorta was homogenised as previously described (Mohammed Yusof et al. 2018b) and used for oxidative stress analysis. An advanced oxidation protein product (AOPP) level was determined based on the AOPP oxidation of $\mathrm{I}^{-}$to $\mathrm{I}_{3}^{-}$under acidic conditions that produced yellow colouration. Absorbance change was measured at $340 \mathrm{~nm}$ wavelength (Witko-Sarsat et al. 1996). Malondialdehyde (MDA) level, an indicator of lipid peroxidation was measured using thiobarbituric acid (TBA) reaction that produces a pink-coloured product called thiobarbituric acid reactive substance (TBARS). The absorbance of TBARS was measured at $532 \mathrm{~nm}$ wavelength (Ledwoż et al. 1986). Reduced glutathione (GSH) level was determined based on Ellman assay, in which 5-5'-dithiobis (2-nitrobenzoic acid) (DTNB) reacts with GSH to form a yellow chromophore, 5-thionitrobenzoic acid (TNB) with a maximum absorbance at $415 \mathrm{~nm}$ (Ellman 1959). Superoxide dismutase (SOD) activity was evaluated based on the NBT-diformanzan reduction assay. Superoxide ions $\left(\mathrm{O}^{2-}\right)$ convert NBT to NBT-diformazan. The presence of SOD reduces $\mathrm{O}^{2-}$ thereby lowering the rate of NBT-diformazan formation, which absorbs light at $560 \mathrm{~nm}$ wavelength (Beyer \& Fridovich 1987).

\section{HISTOLOGICAL EVALUATION}

A small portion of the excised aorta was fixed immediately in formalin and processed using Leica Tissue 
Processor (Leica Biosystem, Germany). The processed tissues were embedded in paraffin and were sectioned at 3-5 $\mu \mathrm{m}$ thickness before stained with Haematoxylin and Eosin stains for microscopic histological evaluation.

\section{DATA AND STATISTICAL ANALYSIS}

All data were expressed as mean \pm standard error of the mean (SEM). Statistical analysis was carried out using one-way ANOVA followed by Tukey multiple comparison tests. Fasting blood glucose and body weight were compared by two-way ANOVA followed by Tukey multiple comparison test. The differences were considered significant at $p<0.05$. All statistical analyses were carried out using GraphPad Prism software (GraphPad Software Inc.V6.01, US).

\section{RESULTS}

\section{SYSTEMIC CHARACTERISTICS}

As shown in Figure 1(A) and 1(B), after four weeks of non-treatment, all diabetic groups showed a significantly higher fasting blood glucose and lower body weight compared to the NDM group $(p<0.05)$. At the end of the study period, DM+HPE and DM+MET groups showed lower fasting blood glucose compared to the DM group. However, only DM+MET group showed a significant reduction $(p<0.05)$. At the end of the eighth week, metformin lowered the blood glucose level in the DM+MET group significantly $(\mathrm{p}<0.05)$ compared to Weeks 4 and 1 . The body weight in all diabetic groups showed no improvement at the end of the study period compared to the NDM group. The DM group also exhibited a significant increase in systolic blood pressure (SBP) and mean arterial blood pressure (MAP) $(\mathrm{p}<0.05)$ compared to the NDM group (Figure 2). SBP and MAP were normalised with HPE treatment.
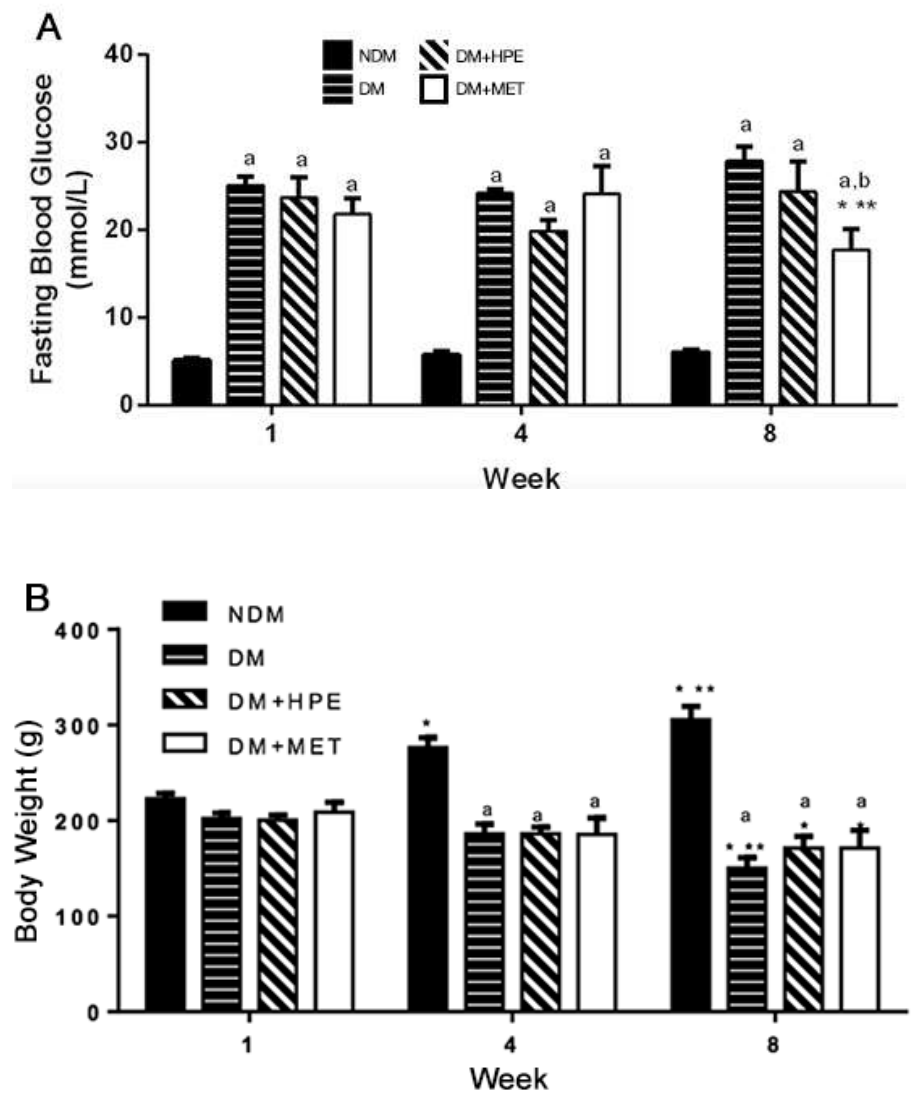

FIGURE 1. Systemic alterations improvement in HPE-treated diabetic rats. Fasting blood glucose (A) and body weight of rats (B) in the control group (NDM), diabetic group (DM), HPE-treated diabetic group (DM+HPE), and metformin-treated diabetic group (DM+MET). Each column and point represent the mean \pm SEM with $\mathrm{n}=6$ for each group. $* \mathrm{p}<0.05$ vs week $1, * *$ $\mathrm{p}<0.05$ vs week $4,{ }^{\mathrm{a}} \mathrm{p}<0.05$ vs NDM, ${ }^{\mathrm{b}} \mathrm{p}<0.05$ vs DM 
A

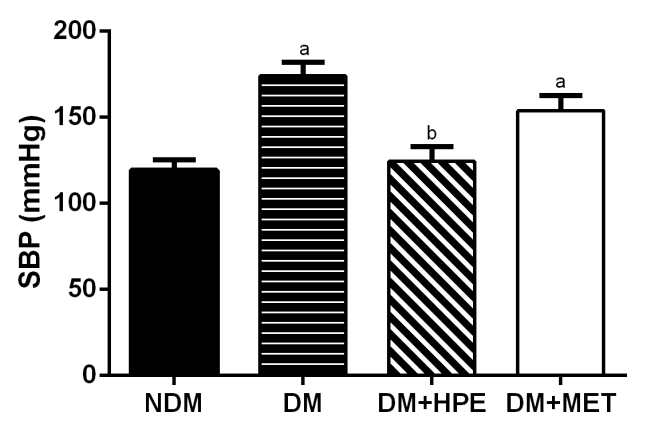

B

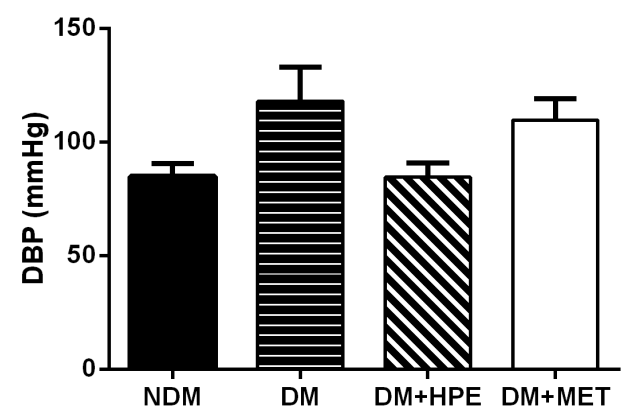

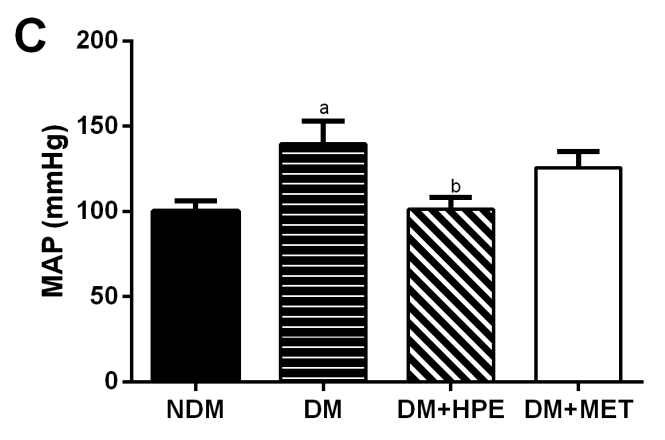

FIGURE 2. Blood pressure alterations improvement in HPE-treated diabetic rats. Systolic blood pressure (SBP) (A), diastolic blood pressure (DBP) (B), and mean arterial pressure (MAP) (C) of rats in control (NDM), diabetic group (DM), HPE-treated diabetic group (DM+HPE), and metformin-treated diabetic group (DM+MET). Each column represents the mean \pm SEM, with $n=6$ for each group. ${ }^{a} \mathrm{p}<0.05$ vs NDM, ${ }^{b} \mathrm{p}<0.05$ vs DM

\section{VASCULAR FUNCTION}

Aortic rings from both the DM and HPE-treated groups showed no demonstration of any significant difference in the sensitivity toward PE-induced vasoconstriction $\left(\mathrm{C}_{\text {max }}\right)$ compared to the NDM group. However, the aortic rings from the metformin-treated group showed a significant reduction in contractile response compared to the DM group (Figure 3(A) and Table 1). All diabetic groups exhibited a significant reduction in response to ACh-induced vasorelaxation $\left(\mathrm{R}_{\max }\right)$ compared to the non- diabetic group. Only the metformin-treated group showed a significant improvement in response to $\mathrm{ACh}$-induced vasorelaxation compared to the diabetic group. Although HPE supplementation showed a trend of improved vasorelaxation (Figure 3(B) and Table 1), no statistical significance was attained. Nonetheless, no significant difference was observed for the aortic relaxation $\left(\mathrm{R}_{\max }\right)$ towards endothelium-independent vasodilator, SNP in all groups (Figure 3(C) and Table 1). 

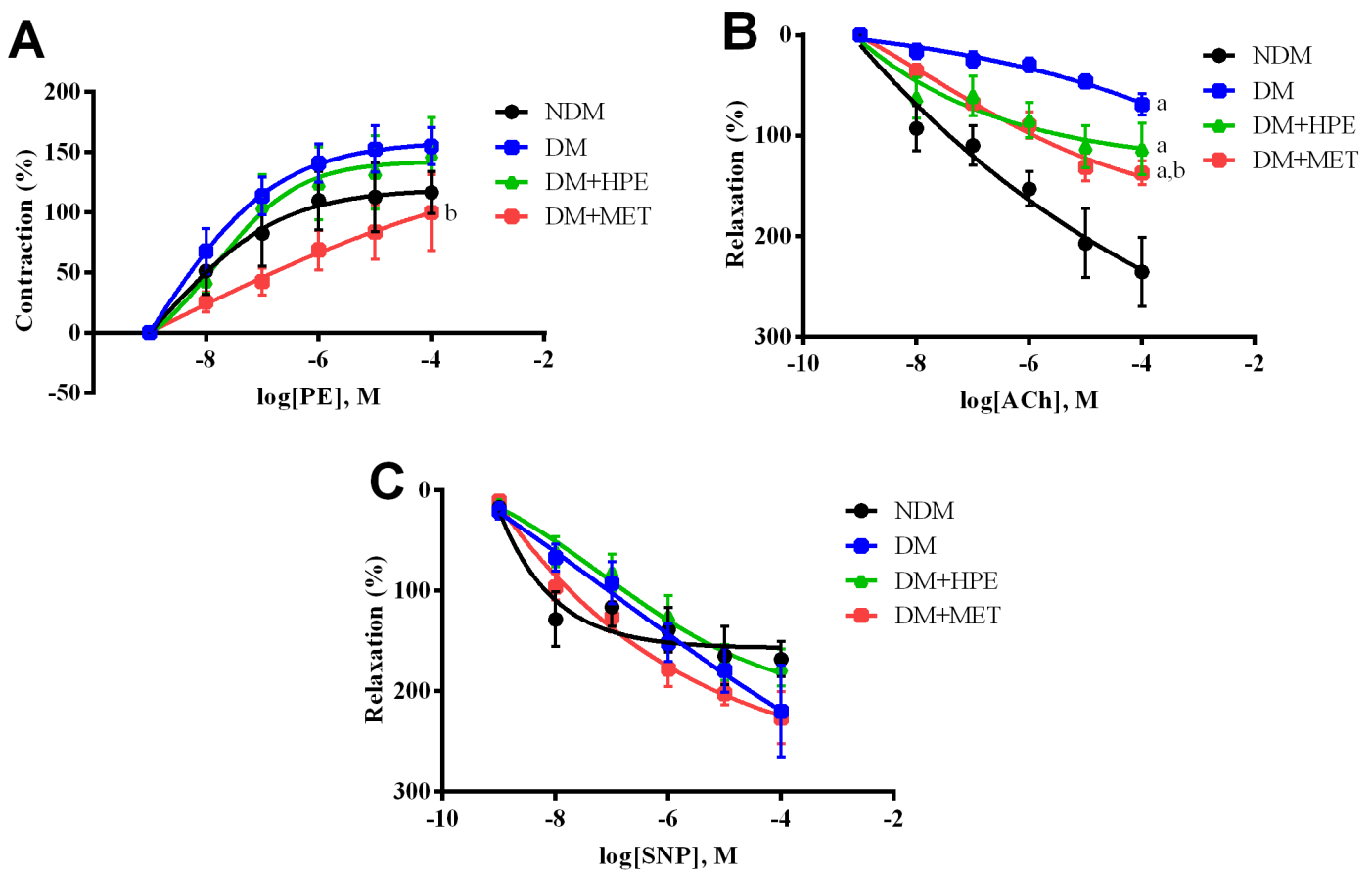

FIGURE 3. Contractile and relaxation responses of aortic rings. The cumulative concentration-response curve for phenylephrine-induced contraction (A), acetylcholineinduced endothelium-dependent relaxation (B), and sodium nitroprusside-induced endothelium-independent relaxation $(\mathrm{C})$ of the aorta from rats in all groups. The contractile responses are expressed as a percentage of maximum contraction by $\mathrm{KCl}$, and the relaxation responses are pre-contracted with $10^{-6} \mathrm{M}$ PE. Each point represents mean \pm SEM with $\mathrm{n}=6$ for each group. ${ }^{\mathrm{a}} \mathrm{p}<0.05$ vs NDM, ${ }^{\mathrm{b}} \mathrm{p}<0.05$ vs DM

TABLE 1. Contraction and relaxation responses characteristics of aortic rings from each group

\begin{tabular}{lcccccc}
\hline \multirow{2}{*}{ Group } & \multicolumn{2}{c}{ Phenylephrine $(\mathrm{PE})$} & \multicolumn{2}{c}{ Acetylcholine (ACh) } & \multicolumn{2}{c}{ Sodium nitroprusside (SNP) } \\
& $\mathrm{C}_{\max }(\%)$ & $\mathrm{pEC}_{50}$ & $\mathrm{R}_{\max }(\%)$ & $\mathrm{pEC}_{50}$ & $\mathrm{R}_{\max }(\%)$ & $\mathrm{pEC}_{50}$ \\
\hline $\mathrm{NDM}$ & $116.27 \pm 9.84^{\mathrm{a}}$ & $7.26 \pm 0.59$ & $235.82 \pm 33.32$ & $7.48 \pm 0.40$ & $188.03 \pm 17.63$ & $7.68 \pm 0.66$ \\
$\mathrm{DM}$ & $154.15 \pm 16.19$ & $7.48 \pm 0.46$ & $69.18 \pm 20.50^{\mathrm{b}}$ & $5.66 \pm 0.55$ & $219.83 \pm 4.54$ & $7.48 \pm 0.46$ \\
$\mathrm{DM}+\mathrm{HPE}$ & $148.98 \pm 3.10$ & $7.34 \pm 0.30$ & $113.49 \pm 21.91^{\mathrm{a}}$ & $6.76 \pm 0.49$ & $176.63 \pm 13.40$ & $6.89 \pm 0.34$ \\
$\mathrm{DM}+\mathrm{MET}$ & $99.63 \pm 3.12^{\mathrm{a}}$ & $6.28 \pm 0.33$ & $137.41 \pm 11.74^{\mathrm{a}}$ & $6.88 \pm 0.37$ & $226.59 \pm 25.97$ & $7.41 \pm 0.32$ \\
\hline
\end{tabular}

Data are expressed as mean \pm SEM. ${ }^{a} \mathrm{p}<0.05$ vs NDM, ${ }^{\mathrm{b}} \mathrm{p}<0.05$ vs DM.

$\mathrm{C}_{\max }$, maximum contraction response; $\mathrm{R}_{\max }$ maximum relaxation response; $\mathrm{pEC}_{50}$ concentration producing $50 \%$ maximal response 


\section{OXIDATIVE STRESS AND ANTIOXIDANT STATUS}

Analysis of oxidative stress and enzymatic antioxidant activities were depicted in Figure 4. Diabetes caused a significant increase in the aortic level of MDA and AOPP compared to the NDM group $(\mathrm{P}<0.05)$. This was accompanied by a remarkable reduction in the antioxidant activities of GSH and SOD. Treatment with HPE not only significantly suppressed MDA and AOPP production in the aortas of the DM rats $(\mathrm{p}<0.05)$, but also showed a trend of improved GSH activities. Conversely, metformin treatment significantly lowered both MDA and AOPP levels whilst concomitantly preserving GSH in the aorta of diabetic rats. SOD was unaffected by diabetes condition and HPE supplementation, however, metformin treatment to diabetic rats caused a significant increment in SOD activity compared to the NDM group.
A

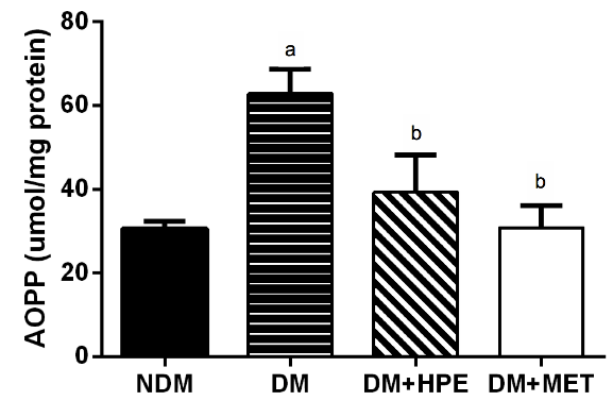

C

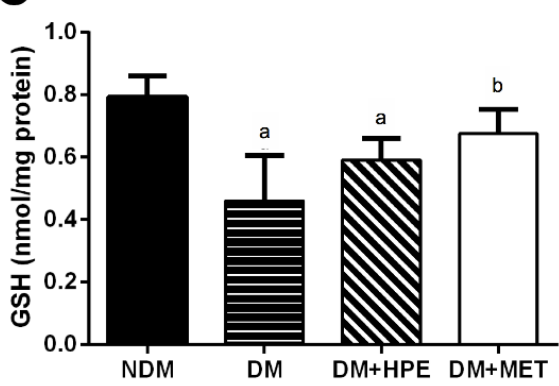

B

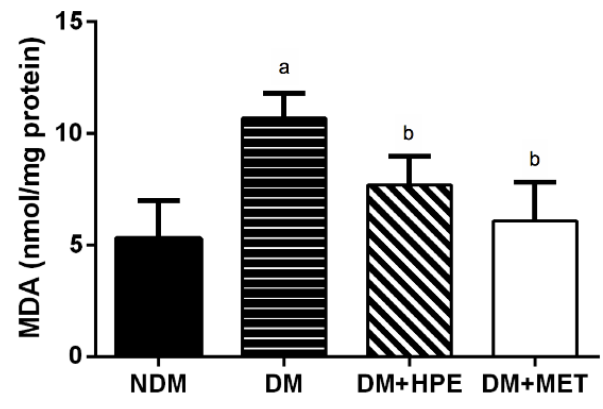

D

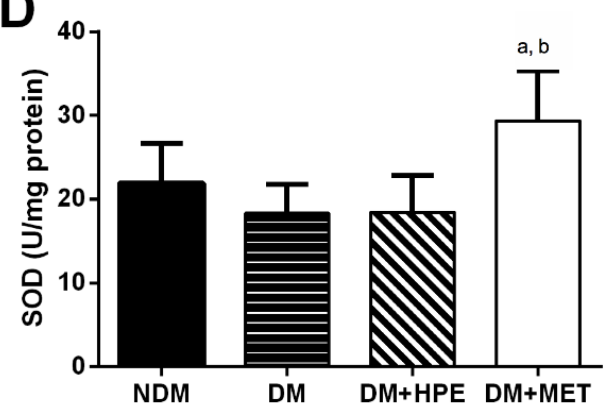

FIGURE 4. (A) Levels of advanced oxidation protein products (AOPP), (B) malondialdehyde (MDA), (C) reduced glutathione (GSH), and (D) superoxide dismutase (SOD) (D) in control (NDM), diabetic group (DM), HPE-treated diabetic group (DM+HPE), and metformin-treated diabetic group (DM+MET). Each column represents the mean \pm SEM with $n=6$ in each group. ${ }^{a} p<0.05$ vs NDM, ${ }^{b} p<0.05$ vs DM 


\section{HISTOLOGICAL OBSERVATION OF THE AORTA}

Under H\&E staining (Figure 5), the structure of vascular smooth muscle cells (VSMCs) in the aorta appeared normal in the NDM group. Normal histology of aorta is indicated by a regular arrangement of the elastic lamina in the tunica media. The nuclei of the VSMCs are single, oval, prominent, and centrally located in the VSMCs. In contrast to the NDM group, the aorta section from the DM group showed an irregular arrangement of the VSMCs. These alterations were improved by both HPE and metformin treatment whereby the arrangement of VSMCs was more organised.
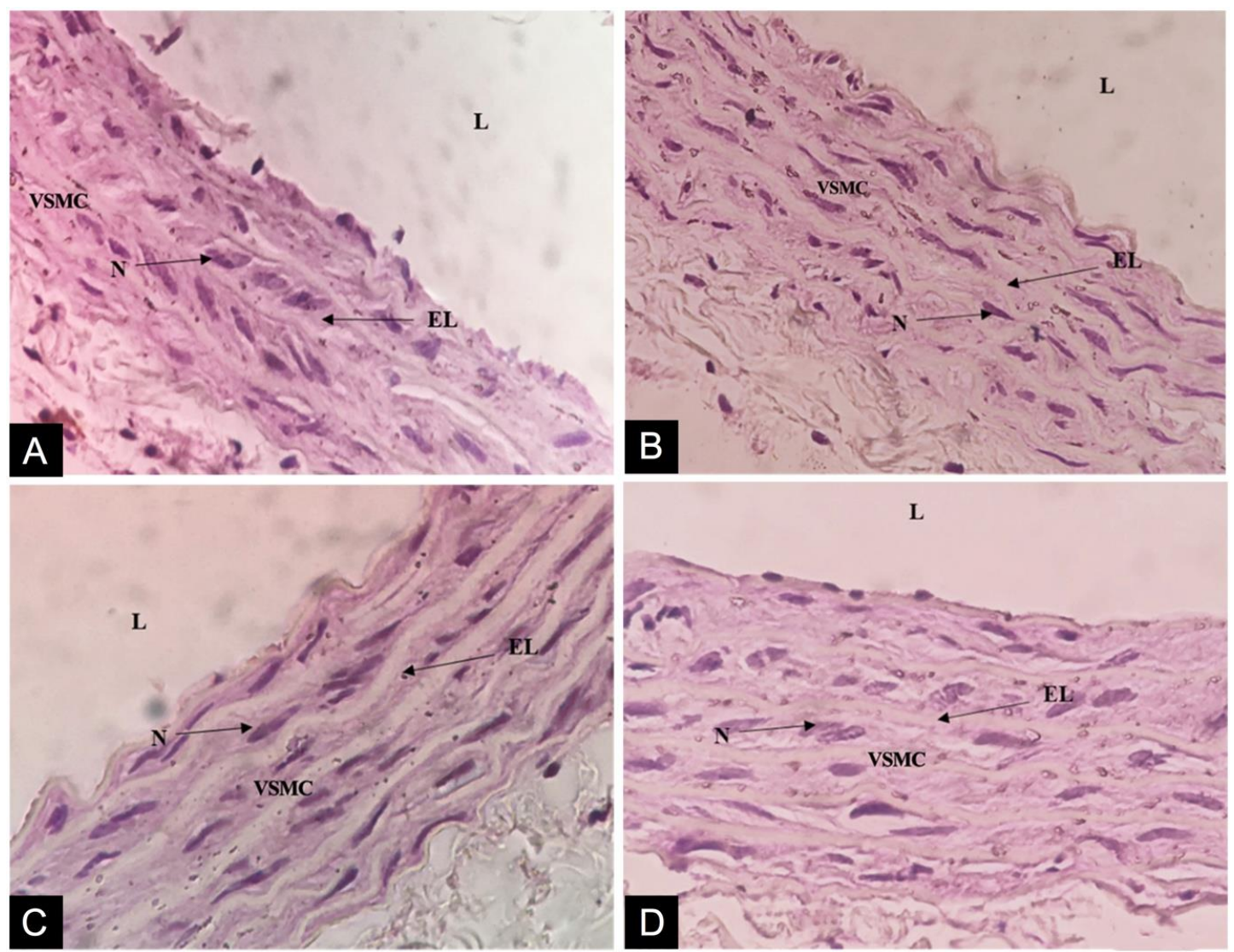

FIGURE 5. Structural alterations in the aorta of rats. Histological examination showing the aortic sections of rats in the (A) control group (NDM), (B) diabetic group (DM),

(C) HPE-treated diabetic group (DM+HPE), and (D) metformin-treated diabetic group (DM+MET) under H\&E stain (X400). Abbreviations: L, lumen; EL, elastic lamina; N, vascular smooth muscle nucleus, VSMC; vascular smooth muscle cells

\section{DISCUSSION}

Previous studies have proved that $H$. sabdariffa Linn. has medicinal antidiabetic (Idris et al. 2012), antioxidative (Ajiboye et al. 2011), antihypertensive (Si et al. 2017), hypocholesterolemic (Ali et al. 2017), and anti-fibrotic effect (Ali et al. 2019). Lim et al. (2017) and Peng et al. (2011) showed that HPE contains organic acids, quercetin, pectin, anthocyanin (delphinidin-3- 
sambubioside and cyanidin-3-sambubioside), phenolic acids, and flavonoids. This study focuses on the benefits of supplementing HPE from $H$. sabdariffa Linn. calyx to reduce oxidative stress and vascular dysfunction in a rat model of type $1 \mathrm{DM}$. Diabetic rats were left untreated for four weeks and were then supplemented with HPE for another period of four weeks. Previous study showed that the supplementation of HPE for 8 weeks starting from the early stage of diabetes (right after diabetic confirmation) improves blood glucose level in diabetic rats (Sena et al. 2011). The finding in this study showed no improvement in the blood glucose level with HPE treatment that started after 4 weeks of the diabetic state. This is probably due to the irreversible and extensive $\beta$-cell damage which cannot be overcome by HPE supplementation.

In this study, the improvement of SBP by HPE is in line with previous studies that suggested the hypotensive action of HPE (Mohammed Yusof et al. 2018a). Although the mechanism underlying the blood pressure-lowering effect of HPE was not investigated in this study, previous studies suggest that HPE may promote diuresis via the action of delphinidin and cyanidin-3-O-sambubiocides compounds (Mohammed Yusof et al. 2018a; Si et al. 2017). H. sabdariffa Linn. extract has been proven to contain both delphinin and cyanidin-3-O-sambubiocides among other compounds including anthocyanin (3-glucoside cyanidine, 3-O-glucosyl-rutinoside cyanidine), chlorogenic acid, hibiscus acid, and flavonoids (quercetin, rutin) (Lim et al. 2017; Maciel et al. 2018). Both delphinin and cyanidin-3-O-sambubiocides were believed to act as angiotensin-converting enzyme (ACE) inhibitors that lower the blood pressure by widening or dilating the blood vessels (Inuwa et al. 2012; Ojeda et al. 2010). Interestingly, this study showed that HPE supplementation improved SBP in diabetic rats. This suggests that HPE exhibits hypotensive action that could be contributed by the presence of ACE-inhibiting compounds.

Vascular dysfunction is an important mechanism involved in the development of hypertension (Giles et al. 2012). Diabetes has been suggested to induce vascular dysfunction through the reduction of nitric oxide (NO) bioavailability in the vessel wall by possibly causing endothelial damage (Giles et al. 2012). According to Si et al. (2017), damage to the endothelium impairs the production of relaxing factors such as NO and may lead to the impairment in vasorelaxation. DM was also reported to diminish endothelial nitric oxide synthase (eNOS) capacity to generate NO (El-Remessy et al. 2010). Vasodilation was improved following an increment in the NO level in the circulation (Yap et al. 2016). In this study, diabetic rats had aortic relaxation impairment in response to ACh. Hence, this suggests that vascular dysfunction occurs in hyperglycaemic conditions, which could be due to the reduced bioavailability of endothelium-derived NO (Jia et al. 2016).

In this study, metformin treatment clearly improved vascular dysfunction in diabetic rats. This finding is in line with a previous study that reported the potential of metformin in alleviating macrovascular reactivity and vascular dysfunction in diabetic condition. However, metformin also comes with a wide range of side effects including gastrointestinal tract disturbance, hypoglycaemia and heartburn (Sanchez-Rangel et al. 2017). Recently, natural products-derived treatment is becoming more popular. Many studies have shown that H. sabdariffa supplementation at the early onset of diabetes exerts cardiovascular protective effect (Ali et al. 2019; Sena et al. 2011). HPE supplementation showed a tendency in improving $\mathrm{ACh}$-induced vasorelaxation in diabetic rats. Antioxidant activities of phenolic compounds have been shown to prevent vascular dysfunction by improving related risk factors such as blood pressure, hyperlipidaemia, and LDL oxidation (Huegel et al. 2016). Antioxidant and anti-inflammatory activities of flavonoids and anthocyanins also augmented NO status, hence improving vascular function (Huegel et al. 2016).

Overproduction of ROS can lead to the development of cardiovascular diseases via an imbalance in antioxidantoxidant status (Kang et al. 2015). Hyperglycaemia in diabetes causes overproduction of ROS and thus, may enhance lipid peroxidation and vascular oxidative damage (Aldosari et al. 2018). This process has been proven as the contributing factor for vascular dysfunction in diabetes (Si et al. 2017). Polyphenols have the ability to suppress oxidation, act as strong antioxidants, neutralise ROS, interrupt the propagation stage of lipid peroxidation chain reactions, and act as metal chelators (Huegel et al. 2016). Therefore, polyphenols are effective in protecting against oxidative damage. Both MDA and AOPP levels were elevated in diabetic rats, which is indicative of oxidative stress. Interestingly, such elevations were significantly normalised with HPE supplementation. Antioxidants can scavenge ROS, thereby promoting vascular function and inhibit vascular oxidative damage (Escribano-Lopez et al. 2018). The mechanisms for the antioxidant effects of HPE were suggested to arise from the ability to scavenge ROS. Furthermore, flavonoids such as epigallocatechingallate found in HPE can reduce ROS overproduction in the endothelial cells (Ahn et al. 2010). 
A previous study suggested that supplementation with polyphenols was able to restore the redox homeostasis by enhancing endogenous antioxidants status such as SOD, catalase, glutathione peroxidase (GPx), and GSH (Wang et al. 2015). The mechanisms of the antioxidant effects of HPE are suggested to arise from their ability to restore antioxidant status. As previously reported, supplementation of antioxidants could provide beneficial protective effects against DM complications (Wong et al. 2019). In this study, the increase in GSH level following HPE treatment might be contributed by the antioxidant activity of HPE that prevents vascular oxidative damage and improves the vasorelaxation in diabetic rats.

According to Harvey et al. (2015), vascular dysfunction and structural changes in the vessel wall contribute to the progression of vascular complications in DM. Improved vasodilation and blunted oxidative damage were suggested to prevent aortic tissue remodelling ( $\mathrm{Si}$ et al. 2017). DM caused vascular remodelling that is involved in the irregular arrangement of tunica media as well as structural changes of VSMCs that are essential contributors to the initiation of atherosclerosis and hypertension (Si et al. 2017). In addition, $H$. sabdariffa Linn. extracts were found to inhibit the proliferation of VSMCs through the downregulation of matrix metalloproteinases-2 (Huang et al. 2009). According to Chen et al. (2003), H. sabdariffa Linn. extract was also able to inhibit atherosclerosis progression via the inhibition of LDL oxidation in the arterial wall. In this study, HPE supplementation is able to improve vascular remodelling, which may contribute to the improvement in vascular function. Further experimental exploration of the mechanistic pathways involved in HPE action on diabetic aorta could support the development of more clinically applicable conditioning strategies against diabetic vascular complications.

\section{CONCLUSION}

This study demonstrated that the administration of HPE attenuated the blood pressure, oxidative stress and vascular wall changes of the aorta in the diabetic rat model. HPE supplementation may, thus, reduces the risk of diabetic vascular complications.

\section{ACKNOWLEDGEMENTS}

We gratefully acknowledge the financial support from the Universiti Kebangsaan Malaysia, Malaysia via Geran
Universiti Penyelidikan research grant (GUP-2017-040). The authors declare no conflict of interest.

\section{REFERENCES}

Ahn, H.Y., Kim, C.H. \& Ha, T.S. 2010. Epigallocatechin-3-gallate regulates nadph oxidase expression in human umbilical vein endothelial cells. Korean Journal of Physiology \& Pharmacology 14(5): 325-329.

Ajiboye, T.O., Salawu, N.A., Yakubu, M.T., Oladiji, A.T., Akanji, M.A. \& Okogun, J.I. 2011. Antioxidant and drug detoxification potentials of Hibiscus sabdariffa anthocyanin extract. Drug and Chemical Toxicology 34(2): 109-115.

Alberti, K.G.M. \& Zimmet, P. 2013. Epidemiology: Global burden of disease - where does diabetes mellitus fit in? Nature Review Endocrinology 9(5): 258-260.

Aldosari, S., Awad, M., Harrington, E., Sellke, F. \& Abid, M. 2018. Subcellular reactive oxygen species (ROS) in cardiovascular pathophysiology. Antioxidants 7: 14.

Ali, R.F. \& El-Alany, A.M. 2017. Hypolipidemic and hypocholesterolemic effect of roselle (Hibiscus sabdariffa L.) seeds oil in experimental male rats. Journal of Oleo Science 66(1): 41-49.

Ali, S.S., Mohamed, S.F.A., Rozalei, N.H., Yap, W.B. \& Zainalabidin, S. 2019. Anti-fibrotic actions of roselle extract in rat model of myocardial infarction. Cardiovascular Toxicology 19(1): 72-81.

Baharom, N., Shamsul Azhar, S. \& Rotina, A.B. 2016. Prevalence of complementary alternative medicine use among patients with type II diabetes in Negeri Sembilan, Malaysia. Med. \& Health 11(2): 257-266.

Beyer, W.F. \& Fridovich, I. 1987. Assaying for superoxide dismutase activity: Some large consequences of minor changes in conditions. Analytical Biochemistry 161(2): 559-566.

Boonla, O., Kukongviriyapan, U., Pakdeechote, P., Kukongviriyapan, V., Pannangpetch, P., Prachaney, P. \& Greenwald, S. 2014. Curcumin improves endothelial dysfunction and vascular remodeling in $2 \mathrm{~K}-1 \mathrm{C}$ hypertensive rats by raising nitric oxide availability and reducing oxidative stress. Nitric Oxide 42: 44-53.

Budin, S.B., Rahman, W.Z.A., Jubaidi, F.F., Yusof, N.L.M., Taib, I.S. \& Zainalabidin, S. 2018. Roselle (Hibiscus sabdiriffa) polyphenol-rich extract prevents testicular damage of diabetic rats. Journal of Pharmaceutical Science 8(2): 65-70.

Chen, C.C., Hsu, J.D., Wang, S.F., Chiang, H.C., Yang, M.Y., Kao, E.S., Ho, Y.C. \& Wang, C.J. 2003. Hibiscus sabdariffa extract inhibits the development of atherosclerosis in cholesterol-fed rabbits. Journal of Agricultural and Food Chemistry 51(18): 5472-5477.

El-Remessy, A.B., Tawfik, H.E., Matragoon, S., Pillai, B., Caldwell, R.B. \& Caldwell, R.W. 2010. Peroxynitrite mediates diabetes-induced endothelial dysfunction: 
Possible role of rho kinase activation. Circulation 114: 311-330.

Ellman, G.L. 1959. Tissue sulfhydryl groups. Archives of Biochemistry and Biophysics 82(1): 70-77.

Escribano-Lopez, I., Diaz-Morales, N., Iannantuoni, F., LopezDomenech, S., De Marañon, A.M., Abad-Jimenez, Z., Bañuls, C., Rovira-Llopis, S., Herance, J.R. \& Rocha, M. 2018. The mitochondrial antioxidant SS-31 increases SIRT1 levels and ameliorates inflammation, oxidative stress and leukocyteendothelium interactions in type 2 diabetes. Scientific Reports 8: 15862 .

Giles, T.D., Sander, G.E., Nossaman, B.D. \& Kadowitz, P.J. 2012. Impaired vasodilation in the pathogenesis of hypertension: Focus on nitric oxide, endothelial-derived hyperpolarizing factors, and prostaglandins. Journal of Clinical Hypertension 14(4): 198-205.

Grundy, S.M. 2012. Pre-diabetes, metabolic syndrome, and cardiovascular risk. Journal of the American College of Cardiology 59(7): 635-643.

Harvey, A., Montezano, A.C. \& Touyz, R.M. 2015. Vascular biology of ageing - Implications in hypertension. Journal of Molecular and Cellular Cardiology 83: 112-121.

Huang, C.N., Chan, K.C., Lin, W.T., Su, S.L., Wang, C.J. \& Peng, C.H. 2009. Hibiscus sabdariffa inhibits vascular smooth muscle cell proliferation and migration induced by high glucose - A mechanism involves connective tissue growth factor signals. Journal of Agricultural and Food Chemistry 57(8): 3073-3079.

Huegel, H.M., Jackson, N., May, B., Zhang, A.L. \& Xue, C.C. 2016. Polyphenol protection and treatment of hypertension. Phytomedicine 23: 220-231.

Idris, M.H.M., Budin, S.B., Osman, M. \& Mohamed, J. 2012. Protective role of Hibiscus sabdariffa calyx extract against streptozotocin induced sperm damage in diabetic rats. Excli. Journal 11: 659-669.

Inuwa, I., Ali, B.H., Al-Lawati, I., Beegam, S., Ziada, A. \& Blunden, G. 2012. Long-term ingestion of Hibiscus sabdariffa calyx extract enhances myocardial capillarization in the spontaneously hypertensive rat. Experimental Biology and Medicine 237(5): 563-569.

Jia, G., Durante, W. \& Sowers, J.R. 2016. Endothelium-derived hyperpolarizing factors: A potential therapeutic target for vascular dysfunction in obesity and insulin resistance. Diabetologia 65(8): 2118-2120.

Kang, P. \& Seol, G.H. 2015. Linalool elicits vasorelaxation of mouse aortae through activation of guanylyl cyclase and $\mathrm{K}+$ channels. Journal of Pharmacy and Pharmacology 67(5): 714-719.

Ledwoż, A., Michalak, J., Stẹpień, A. \& KąDziołka, A. 1986. The relationship between plasma triglycerides, cholesterol, total lipids and lipid peroxidation products during human atherosclerosis. Clinica Chimica Acta 155(3): 275-283.

Lim, Y.C., Budin, S.B., Othman, F., Latip, J. \& Zainalabidin, S. 2017. Roselle polyphenols exert potent negative inotropic effects via modulation of intracellular calcium regulatory channels in isolated rat heart. Cardiovascular Toxicology 17(3): 251-259.

Maciel, L.G., do Carmo, M.A.V., Azevedo, L., Daguer, H., Molognoni, L., de Almeida, M.M., Granato, D. \& Rosso, N.D. 2018. Hibiscus sabdariffa anthocyanins-rich extracts: Chemica stability, in vitro antioxidants and antiproliferative activities. Food and Chemical Toxicology 113: $187-197$

Mohammed Yusof, N.L., Zainalabidin, S., Mohd Fauzi, N. \& Budin, S.B. 2018a. Hibiscus sabdariffa (roselle) polyphenol-rich extract averts cardiac functional and structural abnormalities in type 1 diabetic rats. Applied Physiology, Nutrition, and Metabolism 43(12): 1224 1232.

Mohammed Yusof, N.L., Budin, S.B., Nasir, S.N.M., Yusoff, N.A., Fauzi, N.M. \& Zainalabidin, S. 2018b. Hibiscus sabdariffa (roselle) polyphenol-rich extract prevents the aortic oxidative damage in type 1 diabetic rats. Jurnal Teknologi 80(2): 1-8.

Ojeda, D., Jiménez-Ferrer, E., Zamilpa, A., Herrera-Arellano, A., Tortoriello, J. \& Alvarez, L. 2010. Inhibition of angiotensin convertin enzyme (ACE) activity by the anthocyanins delphinidin-and cyanidin-3-o-sambubiosides from Hibiscus sabdariffa. Journal of Ethnopharmacology 127(1): 7-10.

Peng, C.H., Chyau, C.C., Chan, K.C., Chan, T.H., Wang, C.J. \& Huang, C.N. 2011. Hibiscus sabdariffa polyphenolic extract inhibits hyperglycemia, hyperlipidemia, and glycationoxidative stress while improving insulin resistance. Agricultural and Food Chemistry 59(18): 9901-9909.

Ramalingam, A., Budin, S.B., Lim, Y.C., Si, Y.N.L. \& Zainalabidin, S. 2016. Dietary UKMR-1 roselle supplementation prevents nicotine-induced cardiac injury by inhibiting myocardial oxidative stress. Sains Malaysiana 45(7): 1131-1137.

Ren, Y., Tao, S., Zheng, S., Zhao, M., Zhu, Y., Yang, J. \& Wu, Y. 2016. Salvianolic acid B improves vascular endothelial function in diabetic rats with blood glucose fluctuations via suppression of endothelial cell apoptosis. European Journal of Pharmacology 791: 308-315.

Sanchez-Rangel, E. \& Inzucchi, S.E. 2017. Metformin: Clinical use in type 2 diabetes. Diabetologia 60(9): 1586-1593.

Sena, C.M., Matafome, P., Louro, T., Nunes, E., Fernandes, R. \& Seica, R.M. 2011. Metformin restores endothelial function in aorta of diabetes rats. British Journal of Pharmacology 163(2): 424-437.

Si, L.Y.N., Kamisah, Y., Ramalingam, A., Lim, Y.C., Budin, S.B. \& Zainalabidin, S. Roselle supplementation prevents nicotine-induced vascular endothelial dysfunction and remodelling in rats. Applied Physiology, Nutrition, and Metabolism 42(7): 765-772.

Wang, F., Pu, C., Zhou, P., Wang, P., Liang, D., Wang, Q., Hu, Y., Li, B. \& Hao, X. Cinnamaldehyde prevents endothelial dysfunction induced by high glucose by activating Nrf2 Cellular Physiology and Biochemistry 36(1): 315-324. 
Witko-Sarsat, V., Friedlander, M., Capeillère-Blandin, C., Nguyen-Khoa, T., Nguyen, A.T., Zingraff, J., Jungers, P. \& Descamps-Latscha, B. 1996. Advanced oxidation protein products as a novel marker of oxidative stress in uremia. Kidney International 49(5): 1304-1313.

Wong, S.K., Rangiah, T., Bakri, N.S.A., Ismail, W.N.A., Bojeng, E.E.F., Abd Rahiman, M.A., Soliman, A.M., Ghafar, N., Das, S. \& Teoh, S.L. 2019. The effects of virgin coconut oil on fibroblasts and myofibroblasts on diabetic wound healing. Medicine \& Health 14(2): 132-141.

Yap, W.B., Ahmad, F.M., Lim, Y.C. \& Zainalabidin, S. 2016. Lactobacillus casei strain $\mathrm{C} 1$ attenuates vascular changes in spontaneously hypertensive rats. Korean Journal of Physiology \& Pharmacology 20(6): 621-628.

Zainalabidin, S., Budin, S.B., Anuar, N.N.M., Yusoff, N.A. \& Yusof, N.L.M. 2018. Hibiscus sabdariffa Linn. improves the aortic damage in diabetic rats by acting as antioxidant. Journal of Applied Pharmaceutical Science 8(1): 108114.

Zainalabidin, S., Budin, S.B., Ramalingam, A. \& Lim, Y.C. 2014. Aortic remodelling in chronic nicotine-administered rat. Korean Journal of Physiology \& Pharmacology 18: 411-418.
Fatin Farhana Jubaidi, Lai Ying, Nur Liyana Mohammed Yusof \& Siti Balkis Budin*

Center for Diagnostic

Therapeutic and Investigative Studies (CODTIS)

Faculty of Health Science

Universiti Kebangsaan Malaysia

50300 Kuala Lumpur, Federal Territory

Malaysia

Satirah Zainalabidin

Centre for Toxicology and Health Risk Studies (CORE)

Faculty of Health Sciences

Universiti Kebangsaan Malaysia

50300, Kuala Lumpur, Federal Territory

Malaysia

*Corresponding author; email: balkis@ukm.edu.my

Received: 14 September 2020

Accepted: 2 December 2020 